\title{
In-Vitro Antiproliferative Effect of Cancer Medicine Karumsurathi Thailam on Cultured MCF- 7 Cell Line
}

\author{
R. Mary Suja ${ }^{1}$, B. Christudhas Williams ${ }^{2}$ \\ ${ }^{1}$ Director William Research Centre Nagercoil - 3 India \\ ${ }^{2}$ Assistant Professor Department of Botany and Research Centre, Scott Christian College (Autonomous) Nagercoil, India
}

\begin{abstract}
The main objective of the present investigation is to evaluate the phytochemical constituents, cytotoxic and antiproliferative effect of Karumsurathi Thailam prescribed by the Traditional Siddha Practitioner of Kanyakumari District, India. The external form of Breast Cancer medicine prescribed above 18 years was prepared with 18 different plant ingredients. Phytochemical analysis of the Thailam, aqueous, silver nitrate and ethanol extract revealed the presence of alkaloid, flavanoid, saponin, terpenoid and steroid constituents. Karumsurathi Thailam was tested against human breast cancer cell lines (MCF-7) and antigrowth effect was assessed by the MTT assays. L929 Fibroblast cells treated with Karumsurathi Thailam showed a decrease in viability when compared with the control. A significant decrease in cell viability of $56.10 \%(1 \mu \mathrm{g} / \mathrm{ml}), 50.10 \%(5 \mu \mathrm{g} / \mathrm{ml}), 42.5 \%(10 \mu \mathrm{g} / \mathrm{ml})$ and $40.92 \%(20 \mu \mathrm{g} / \mathrm{ml}) \mathrm{was}$ observed. The cytotoxic activity on cultured 1929 cells and antiproliferative effect on MCF-7 cultured cells revealed the effect of Karumsurathi Thailam as a great potential source to rid and relapse from Breast Cancer.
\end{abstract}

Keywords: Siddha, Kalanchi, MTT assay, Karumsurathi Thailam, MCF-7

\section{Introduction}

Cancer is a worldwide dilemma of grave nature and it is the second leading cause of death next to cardiac diseases throughout the globe. Siddha system is one of the pioneer systems of medicine among traditional medicinal practices in India. Scientific documentation of traditional system of medicine is increasing and need for preparing it for Siddha formulation has become a need of the hour, receives the attraction of Indian Health Ministry and Indian Medical Association. A conference was cosponsored by the United Nations Educational, Scientific and Cultural Organization produced a declaration recognizing that "Traditional and local knowledge systems, as dynamic expressions of perceiving and understanding the world proficient, historically encompass a valuable contribution to science and technology" [1]. The therapeutic value of medicinal plants depends upon the existence of one or more constituents possessing certain physiological and pharmacological activity [2]. Breast cancer develops from breast tissue signs of breast cancer may include a lump in the breast, a change in breast shape, dimpling of the skin and fluid coming from the nipple or a red scaly patch of skin [3].

\section{Materials and Methods}

Collection of Plant Materials and Formulation of Medicine

The plant materials were collected from unpolluted rural areas of India and other ingredients were procured from commercial Siddha raw drug store was authenticated and prepared by My Family Members (Siddha Traditional Practitioner). All the ingredients were shade dried, powdered and sieved was formulated into medicines and stored in porcelain pots for further use. The Siddha formulation were prepared as prescribed in the written scripts, books and palm leaf parchments of My Grandpa and Forefathers Traditional Vadiyars (Table -1).

Table 1: Composition of Karumsurathi Thailam/Oil

\begin{tabular}{|c|l|l|l|}
\hline S.No & Siddha Name & Scientific Name & Quantity \\
\hline 1 & Karunjurai & Capparis sepiaria & 1 Kalanchi \\
\hline 2 & Kottamalli & Coriandrum sativum & 2 Kalanchi \\
\hline 3 & Sadamanjil & Nordostachys jatamansi & 1 Kalanchi \\
\hline 4 & Kombarakku & Cateria lacca & 1 Kalanchi \\
\hline 5 & Venkungiliyam & Shorea robusta & 2 Kalanchi \\
\hline 6 & Karamjiragam & Nigella sativa & 1 Kalanchi \\
\hline 7 & Chukku & Zingiber officinale & 1 Kalanchi \\
\hline 8 & Milagu & Piper nigrum & 1 Kalanchi \\
\hline 9 & Thippili & Piper longum & 1 Kalanchi \\
\hline 10 & Elam & Elleteria cardamom & 2 Kalanchi \\
\hline 11 & Athimathuram & Glycyrrhiza glabra & 1 Kalanchi \\
\hline 12 & Chitarathai & Alpinia calcarata & 1 Kalanchi \\
\hline 13 & Veppampattai & Azadirachta indica & 2 Kalanchi \\
\hline 14 & Seenthil & Tinospora cordifolia & 1 Kalanchi \\
\hline 15 & Nallai Ennai & Sesamum indicum & 1 Kalanchi \\
\hline 16 & Thenkai Ennai & Cococus nucifera & 1 Kalanchi \\
\hline 17 & Pasum Pal & Bos indicus & 1 Kalanchi \\
\hline 18 & Vaalmilagu & Piper cubeba & 2 Kalanchi \\
\hline
\end{tabular}

Phytochemical Screening, Cytotoxic and Antiproliferative Assay of Karumsurathi Thailam

Phytochemical analysis of the Karumsurathi Thailam, aqueous, silver nitrate and ethanol extract of medicine were carried out to analyse the presence of alkaloid, flavanoid, phenol, terpenoid, saponin, reducing sugar, tannin, steroid and glycoside constituents $\left[\begin{array}{lll}4 & \& & 5\end{array}\right]$, cytotoxic and antiproliferative assay [6].

\section{Result}

\section{Qualitative Analysis}

Phytochemical analysis of Karumsurathi Thailam (oil) revealed the presence of alkaloid, flavanoid, saponin, 


\section{International Journal of Science and Research (IJSR) \\ ISSN (Online): 2319-7064 \\ Index Copernicus Value (2015): 78.96 | Impact Factor (2015): 6.391}

terpenoid and steroid constituents. On the other hand, aqueous extract of the Karumsurathi Thailam revealed the presence of alkaloid, flavanoid and saponin constituents. Meanwhile, ethanolic extract of the Karumsurathi Thailam revealed the presence of alkaloid, saponin and steroid constituents. However, silver nitrate assorted in Karumsurathi Thailam revealed the presence of alkaloid, phenol and steroid constituents (Table: 2).

Table 2: Qualitative Analysis of Karumsurathi Thailam and extracts

\begin{tabular}{|c|c|c|c|c|c|}
\hline S.No & Phytochemicals & $\begin{array}{c}\text { Karumsurathi } \\
\text { Thailam }\end{array}$ & Aqueous & Ethanol & $\begin{array}{c}\text { Silver } \\
\text { nitrate }\end{array}$ \\
\hline 1 & Alkaloid & + & + & + & + \\
\hline 2 & Flavanoid & + & + & - & - \\
\hline 3 & Saponin & + & + & + & - \\
\hline 4 & Phenol & - & - & - & + \\
\hline 5 & Terpenoid & + & - & - & - \\
\hline 6 & Reducing Sugar & - & - & - & - \\
\hline 7 & Tannin & - & - & - & - \\
\hline 8 & Steroid & + & - & + & + \\
\hline 9 & Glycoside & - & - & - & - \\
\hline
\end{tabular}

+ Presence - Absence

Cytotoxic Effect of Karumsurathi Thailam on Cultured 1929 Cells

The observed results strongly profile that there was a concentration dependent cytotoxic effect of Karumsurathi Thailam. L929 Fibroblast cells treated with Karumsurathi Thailam showed a decrease in viability when compared with the control. On the otherhand, a significant decrease in cell viability of $56.10 \%(1 \mu \mathrm{g} / \mathrm{ml}), \quad 50.10 \% \quad(5 \mu \mathrm{g} / \mathrm{ml}), 42.5 \%$ $(10 \mu \mathrm{g} / \mathrm{ml})$ and $40.92 \%(20 \mu \mathrm{g} / \mathrm{ml})$ was observed (Table: 3$)$. The total cell count of L929 Fibroblast cells was decreasing with increase in concentration of the Karumsurathi Thailam indicating an inhibitory effect on the cancer cell line (Plate$1)$.

Table 3: Cytotoxic effect of Karumsurathi Thailam

\begin{tabular}{|c|c|c|}
\hline $\begin{array}{c}\text { Samples Volume } \\
(\mu \mathrm{l})\end{array}$ & $\begin{array}{c}\text { OD Values } \\
(540 \mathrm{~nm})\end{array}$ & $\begin{array}{c}\text { Percentage } \\
\text { Viability }\end{array}$ \\
\hline Control & 0.3501 & 100 \\
\hline 1 & 0.2536 & 56.10619 \\
\hline 5 & 0.2301 & 50.90708 \\
\hline 10 & 0.1921 & 42.5 \\
\hline 20 & 0.185 & 40.9292 \\
\hline
\end{tabular}

Plate-1 Cytotoxic effect of Karumsurathi Thailam Control

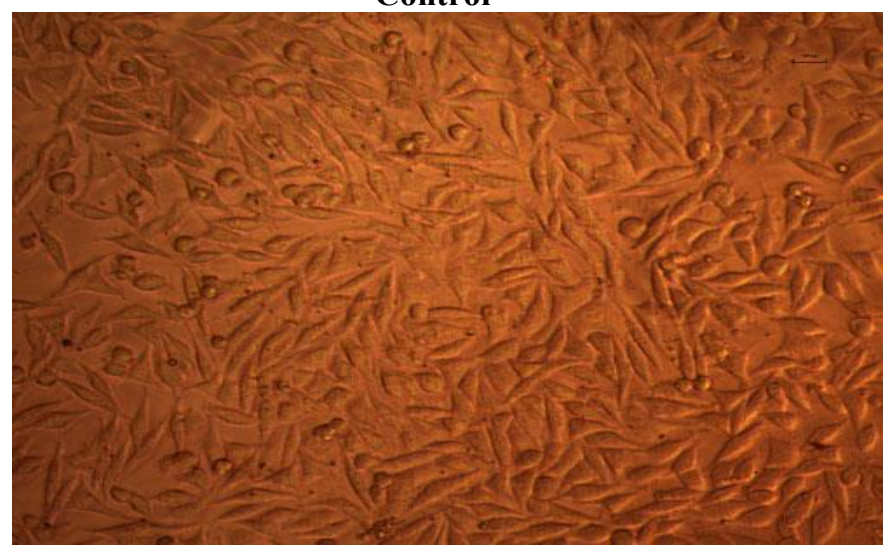

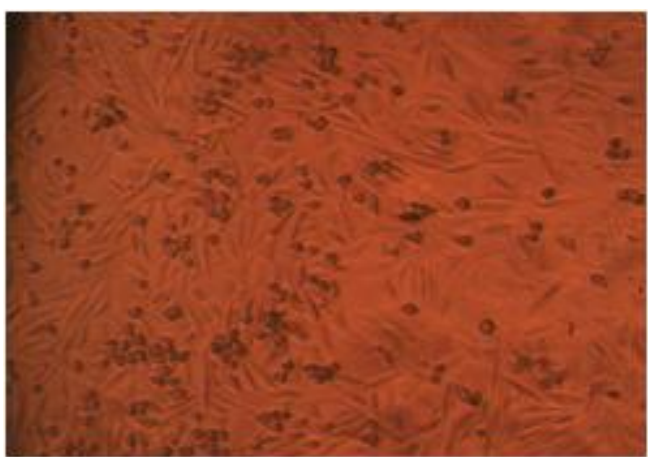

$1 \mu \mathrm{g} / \mathrm{ml}$

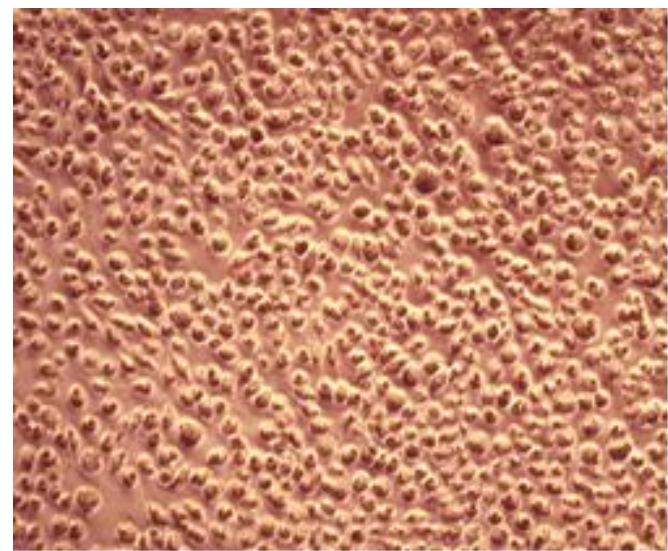

$10 \mu \mathrm{g} / \mathrm{ml}$

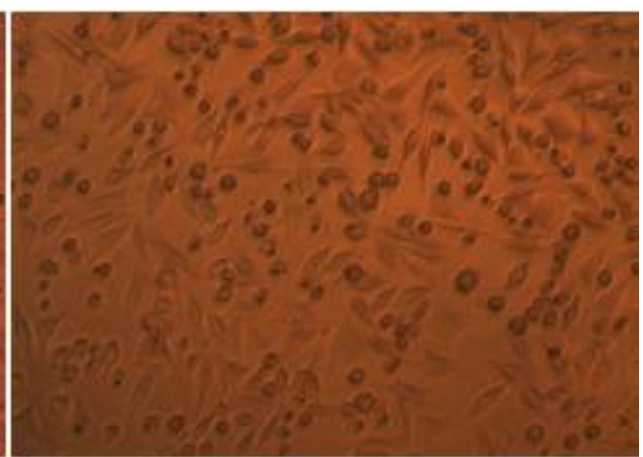

$5 \mu \mathrm{g} / \mathrm{ml}$

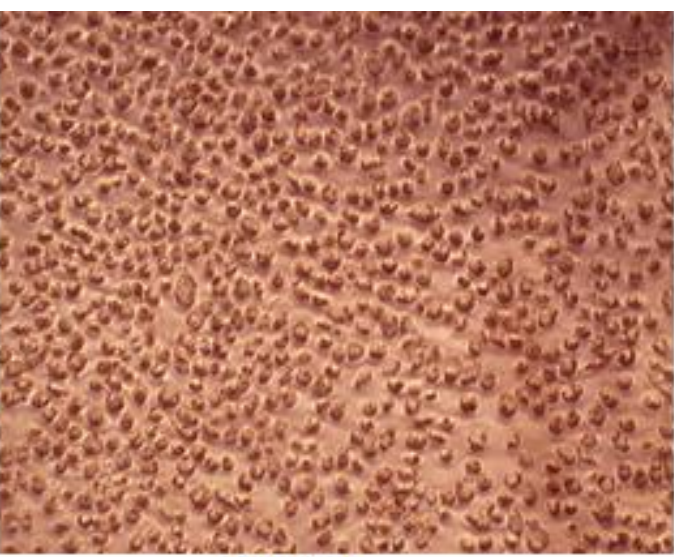

$20 \mu \mathrm{g} / \mathrm{ml}$

Volume 6 Issue 1, January 2017 www.ijsr.net 


\section{International Journal of Science and Research (IJSR) \\ ISSN (Online): 2319-7064 \\ Index Copernicus Value (2015): 78.96 | Impact Factor (2015): 6.391}

Determination of in-vitro antiproliferative effect of Karumsurathi Thailam on cultured MCF-7 cell line

The observed results strongly profile that there was a concentration dependent antiproliferative effect of Karumsurathi Thailam. MCF-7 cells treated with Karumsurathi Thailam showed a decrease in viability when compared with the control. On the otherhand, a significant decrease in cell viability of $89.48 \%(1 \mu \mathrm{g} / \mathrm{ml}), 79.60 \%$ $(5 \mu \mathrm{g} / \mathrm{ml}), 71.37 \%(10 \mu \mathrm{g} / \mathrm{ml})$ and $51.84 \%(20 \mu \mathrm{g} / \mathrm{ml})$ was observed (Table: 4$)$. The total cell count of MCF-7 cells was decreasing with increase in concentration of the Karumsurathi Thailam indicating an inhibitory effect on the cancer cell line (Plate-2).

Table 4: Antiproliferative effect of Karumsurathi Thailam \begin{tabular}{|l|l|l|}
\hline Sample Volume $(\mu \mathrm{l})$ & Average OD at 540nm & Percentage Viability \\
\hline
\end{tabular}

\begin{tabular}{|c|c|c|}
\hline Control & 0.3501 & 100 \\
\hline 1 & 0.3133 & 89.48872 \\
\hline 5 & 0.2787 & 79.60583 \\
\hline 10 & 0.2499 & 71.37961 \\
\hline 20 & 0.1815 & 51.84233 \\
\hline
\end{tabular}
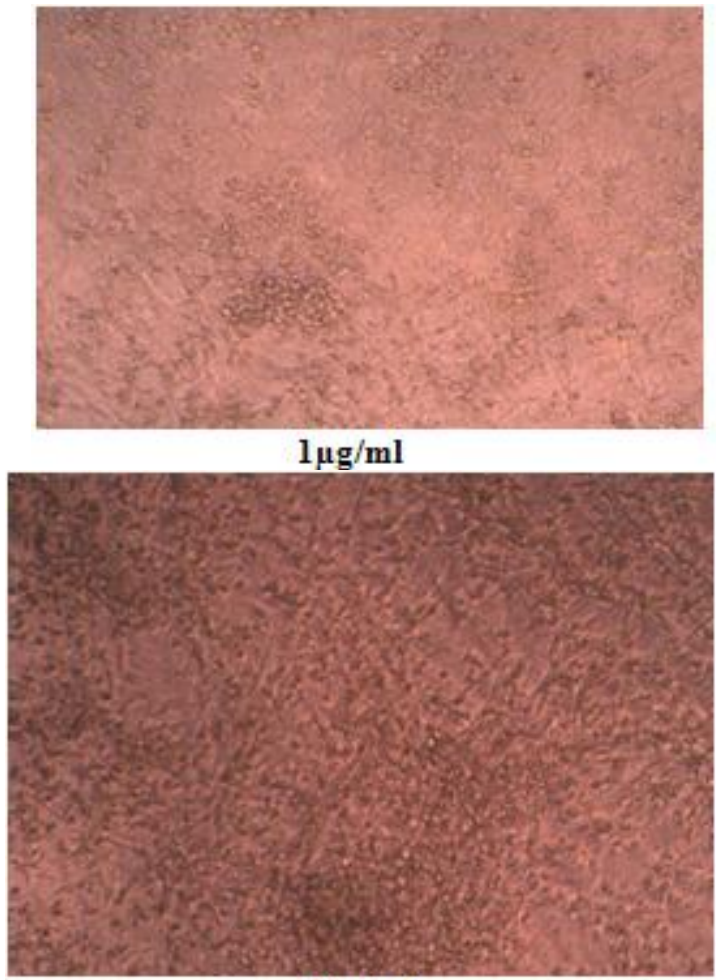

$10 \mu \mathrm{g} / \mathrm{ml}$

\section{Conclusion}

The presence of phytochemicals, cytotoxicity and antiproliferative activity of Karumsurathi Thailam clearly indicate that the prescribed herbal formulation act as a possible source to rid from Cancer.

\section{Acknowledgements}

Reverential thanks to my Grandpa's and My Family Members, Traditional Siddha Practitioners for their treasure of knowledge in the field of Siddha Medicine and providing medicine to carry out the research. I express my whole hearted thanks and indebtedness to my Guide for his
Plate-2 Antiproliferative effect of Karumsurathi Thailam Control
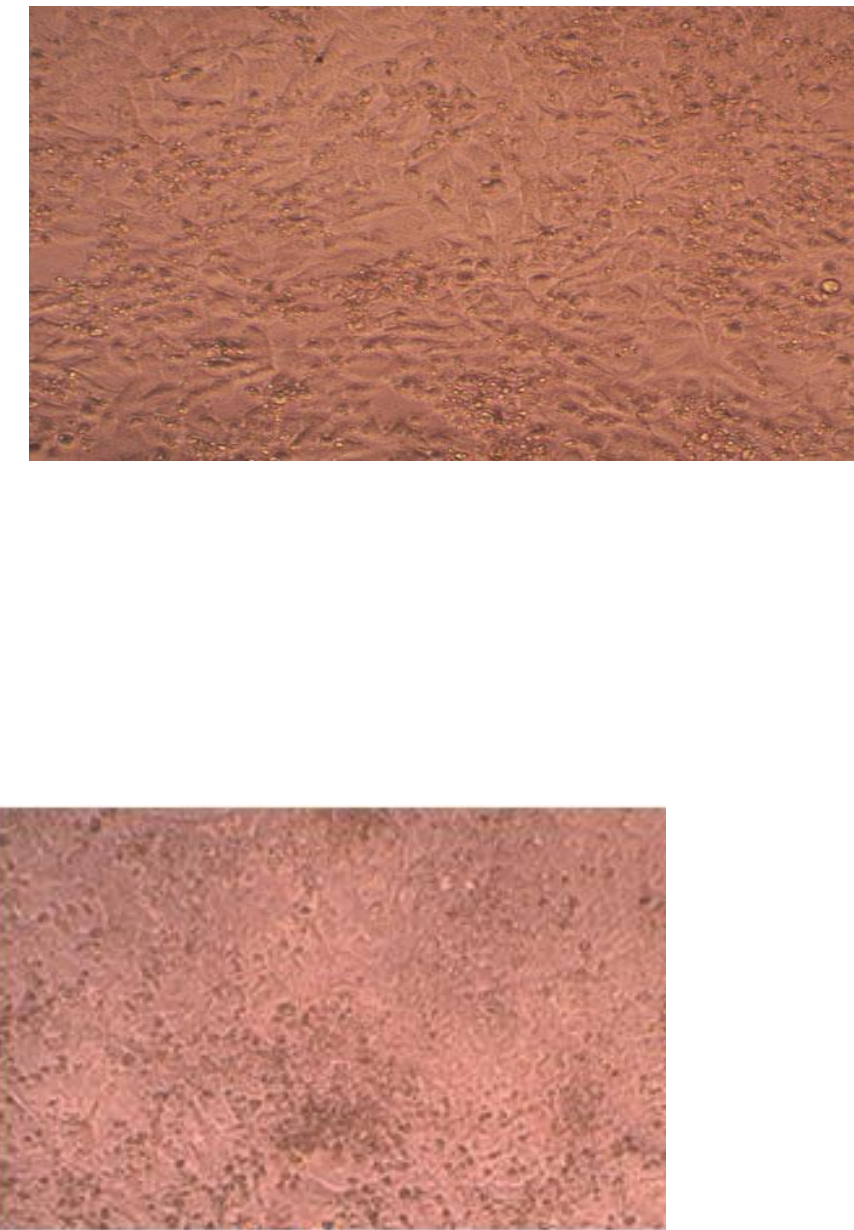

$5 \mu \mathrm{g} / \mathrm{ml}$

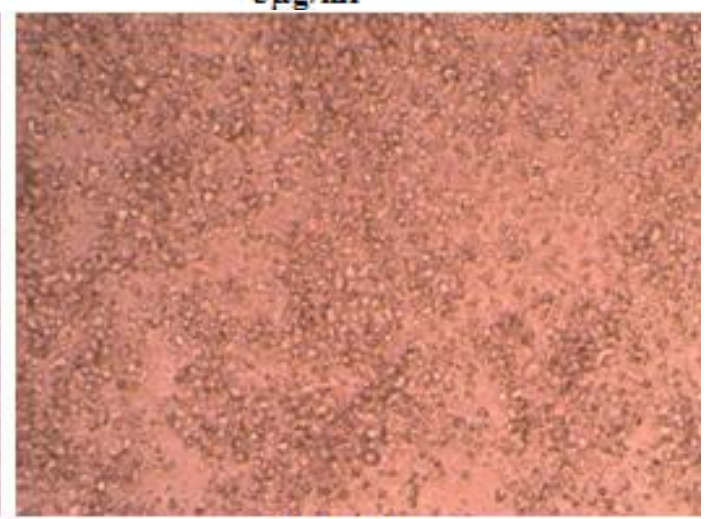

$20 \mu \mathrm{g} / \mathrm{ml}$

valuable guidance. Prayerful thanks to my Parents, Sister and Brother for their warm support, encouragement and prayers.

\section{References}

[1] Thirunanasundari T, Traditional medical knowledge of tribals of Kodai hill (2014). National Conference on Indian Herbal Drugs. 1: 2-3.

[2] Gandhiraja, N S. Sriram, V. Meenaa, J. KavithaSrilakshmi, C. Sasikumar and R.Rajeswari 2009. Phytochemical Screening and Antibacterial Activity of the Plant Extracts of Mimosa pudica L. Against Selected Microbes, Ethnobotanical Leaflets 13:618-24.

\section{Volume 6 Issue 1, January 2017




\section{International Journal of Science and Research (IJSR) \\ ISSN (Online): 2319-7064}

Index Copernicus Value (2015): 78.96 | Impact Factor (2015): 6.391

[3] "Breast Cancer Treatment (PDQ $\left.{ }^{\circledR}\right) "$. NCI. 2014-05-23. Retrieved 29 June 2014.

[4] Allen ST. Chemical analysis of Ecological Material. New York: Blackwell Scientific Publication; 1974. P. 313.

[5] Harbone JR. Phytochemical Methods. A Guide to Modern Techniques of Plant Analysis, London: Charpan and Hall; 1976. P. 78.

[6] Arung ET, Shimizu K, Kondo R. Inhibitory effect of isoprenoid-substituted flavonoids isolated from Artocarpus heterophyllus on melanin biosynthesis. Planta Med, 2006; 72: 847-850. 